\title{
Identification and Prioritisation of Impact Factors in Quality Service of ICICI Bank with Special Reference to Urban Cities of Telangana State
}

\author{
K. Vinaya Laxmi, P. Vijaya Kumar, M. S. Narayana
}

\begin{abstract}
The research mainly deliberates to examine the influencing level of governing client retail service satisfaction towards ICICI banking. A five point likert scale was used to construct the questionnaire with 21 multivariate questions and collected data from 502 respondents, correlation and regression were the tools of statistics used to measure the level of impact of the factors on client satisfaction. Inferences were drawn based on the findings of the study. Questions were framed based on the SERVQUAL dimensions to examine consumer service quality provided by ICICI bank in Hyderabad, Rangareddy and Medak districts and data was collected from concerned account holders in the bank branches. Correlation and regression were used as the tools of analyses. According to the inferences drawn there is a mere influence of the quality service factor dimensions and the client contentment level which was considered very significant. The banks to make a increased client share in the dynamic market has to focus in the stunted areas of development and strengthen their client force.
\end{abstract}

KeyWords - Perception, Tangibility, Assurance, Reliability, Responsiveness, Client satisfaction

\section{INTRODUCTION}

The banking has been the life blood of the financial structure of the country. The paradigm changes taking place in the banking sector has led the inclusive approach an undeniable aspect to imply with technological changes in the organizational structure and product development according to convenience of client requirements. The researcher in this article is mainly focused to measure the quality of retail banking services in ICICI bank. Though the services are upgraded with the mobile and internet work to increase the comfort ability of the client their perceptional gap is still a dearth with the services they receive from banks. The quality service orientation of banks has become a crucial factor in helping the customer retention in the long run and leads to positive word of mouth and increase in client base.

Revised Manuscript Received on July 09, 2019.

K.Vinaya Laxmi, Research Scholar, JNTUK, Kakinada Andhra Pradesh, India

Dr. P. Vijay Kumar, Chairman BOS, HOD Business School of Management, JNTUK Kakinada, Andhra Pradesh, India

Dr. M. S. Narayana, Professor in Business Management, KL University Vijayawada. Andhra Pradesh, India
As there is a change in the perceptions of the clients, a shift from need to need with care and comfort in service is being identified and these anticipations has become inevitable to modify the policy and make priorities with the client facility developments. SERVQUAL is a research scale where dimensions to be measured are the defined perceptions of the customers which they expect from the services of the bank. Reliability is considered as the performance of the employee with high accuracy and punctuality. Assurance is the self-reliance build by the bankers towards the buyers in fulfilling their duties. Tangibility is the assurance of ambience facility to the account holders of the bank. Empathy is the concern shown with attentiveness by a banker towards customer whenever a problem is adhered in the banking activities. Responsiveness is the agreeableness of the banker to help the consumer with quick service, Parsuraman et.al.,1988.

\section{A.Objectives}

The main objective of the research is to identify the level of impact of various SERVQUAL factors over the customer satisfaction with respect to ICICI in Hyderabad, Rangareddy and Medak districts of Telangana state.

Ho: There is no relationship and impact of the retail banking services with SERVQUAL factor dimensions on the customer satisfaction of the ICICI bank in Hyderabad, Rangareddy and Medak districts in Telangana state.

\section{B. Review of Literature}

Many researches were taken on an extensive study to evaluate the concepts of rational and approachable manners of response by the clients in banking services. Yavas and E. Babakus 2005, A bank can reach the customers satisfaction, when they recognize the gaps in needs of clients and fulfill them through quality serviceability. A research in the one of the study by Winstanley. M. 1996, reveals that satisfaction was enhanced by the relationship maintained by public officers, the quality of value added services provided to customers. Customer loyalty and restructuring of the product or service was a clear description of development made by the authors, Churchill and suprenant, 1982, Parsuraman et al 1985,1988; Gronroos 1984 has explained in his study about the attributes dimensions of service quality are based on conceptualization of service quality , cadott et al, 1987, fornell 1992, Zeithmal et al 


\section{Identification and Prioritisation of Impact Factors in Quality Service Of ICICI Bank with Special Reference to Urban Cities of Telangana State}

1996, oliver, 1997. The SERVQUAL model developed by Parsuraman et al revealed that the gap between consumer perception by service and expectation of the quality service through ten various dimensions. Cronin and Taylor 1992 has discussed that the research taken up by Parsuraman in 1985, 1988 was much analyzing the performance analysis of the bank rather than service quality measures. Kang and James 2004, discussed that the SEVQUAL concentrated on service delivery process rather than on the technical scopes i.e., attributes of the service.

Based on the researches taken up there are analyses arrived with customer satisfaction and their attributes identification in the retail banking sector of various countries. But most specifically the individual bank performance and their influencing service dimensions locally in Hyderabad, Ranga Reddy and Medak regions in Telangana state are still a deficiency found. Fulfilling the gap the researcher in this article has taken a leading private sector bank ICICI for study.

\section{RESEARCH METHODOLOGY}

A questionnaire with a five point likert scale was used and a sample of 502 respondents was considered for feedback.. 21 various questions were framed and analyzed based on the operating activities and responsiveness given by the bankers to the clients of the bank. To test the level of contentment by the clientele for facilities delivered by the bank we used the tools such as correlation and regression. Chronbach's alpha was used to test the scale internal reliability.

\section{Limitations of the Study}

The Study's purview is restricted to the private sector bank ICICI and its region of study with three district branches such as Hyderabad, Rangareddy and Medak districts. The study is also restricted with its time period of the data collection from September2017 to August 2018.

\section{Data Analysis}

To test the scale with internal dimension consistency the following chronbach's alpha is measured.

\section{Table No:1}

\begin{tabular}{|l|l|l|}
\hline Particulars & $\begin{array}{l}\text { Chronbach's } \\
\text { alpha }\end{array}$ & No. of Items \\
\hline I Assurance & .826 & 4 \\
\hline II Empathy & .910 & 6 \\
\hline III Reliability & .802 & 4 \\
\hline IV. Responsiveness & .854 & 3 \\
\hline V. Tangibility & .920 & 4 \\
\hline
\end{tabular}

From the table no. 1 we can assume Cronbach's alpha has been run to check the reliability of scale in dimension wise. The alpha value of the all items of retail Banking Services assurance, empathy, reliability, responsiveness, tangibility, explains uni dimensionality characteristics. All the values obtained are

greater than 0.7 , indicates a very strong internal stability among the given items in the scale.

\section{E. Correlation}

Table No: 2

\begin{tabular}{|c|c|c|c|c|}
\hline \multicolumn{2}{|l|}{ Variables } & \multirow{2}{*}{$\begin{array}{l}\begin{array}{l}\text { Correlatio } \\
\text { n Value }\end{array} \\
.249\end{array}$} & \multirow{2}{*}{$\begin{array}{c}\begin{array}{c}\text { Sig. } \\
\text { Valu } \\
\text { e }\end{array} \\
0.00 \\
0\end{array}$} & \multirow{2}{*}{ 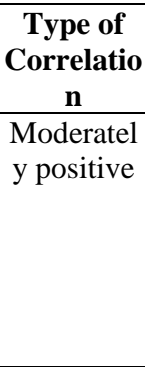 } \\
\hline Tangibility & $\begin{array}{l}\text { Customer } \\
\text { Satisfactio } \\
\mathrm{n} \text { towards } \\
\text { retail } \\
\text { banking } \\
\text { services } \\
\text { of ICICI }\end{array}$ & & & \\
\hline Reliability & $\begin{array}{l}\text { Customer } \\
\text { Satisfactio } \\
\mathrm{n} \text { towards } \\
\text { retail } \\
\text { banking } \\
\text { services } \\
\text { of ICICI } \\
\end{array}$ & .379 & $\begin{array}{c}0.00 \\
0\end{array}$ & Positive \\
\hline $\begin{array}{l}\text { Responsivene } \\
\text { ss }\end{array}$ & $\begin{array}{l}\text { Customer } \\
\text { Satisfactio } \\
\mathrm{n} \text { towards } \\
\text { retail } \\
\text { banking } \\
\text { services } \\
\text { of ICICI }\end{array}$ & .457 & $\begin{array}{c}0.00 \\
0\end{array}$ & Positive \\
\hline Empathy & $\begin{array}{l}\text { Customer } \\
\text { Satisfactio } \\
\mathrm{n} \text { towards } \\
\text { retail } \\
\text { banking } \\
\text { services } \\
\text { of ICICI }\end{array}$ & .349 & $\begin{array}{c}0.00 \\
0\end{array}$ & Positive \\
\hline Assurance & $\begin{array}{l}\text { Customer } \\
\text { Satisfactio } \\
\mathrm{n} \text { towards } \\
\text { retail } \\
\text { banking } \\
\text { services } \\
\text { of ICICI }\end{array}$ & .341 & $\begin{array}{c}0.00 \\
0\end{array}$ & Positive \\
\hline
\end{tabular}

Inference:

From the table two it is obvious that the correlation between tangibility and customer satisfaction is .249 where it specifies that the factor tangibility is positively but moderately correlated according to the customers point of view. Though the bank is efficient with the ways of maintaining attractive facilities but still the client is facing problem with the appearance and transparency with the expression of accessibilities in the bank. Reliability is the factor having the correlation value of .379 which is having a positive value and more than the tangibility in the client point of view, where they believe that whenever a client faces a problem it is being given solution at the minimum mean time.

Responsiveness is being the highest with a correlation value of .457 indicating the prompt service and helpful nature towards the client service.

Empathy is moderately correlated with the satisfaction, where the value is .349 less than reliability and more than tangibility, which specifies personal attention towards client is utmost estimated by the customers.

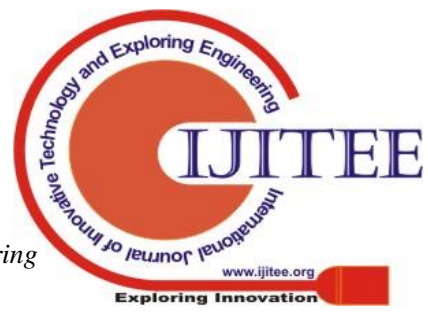


Assurance is .341 and being less than empathy and tangibility revealing that the customers expect little more with safe and secured transactions, high confidence in transactions and more courteousness from staff of the bank.

\section{F. Regression}

Table No: 3

\begin{tabular}{|c|c|c|c|c|c|}
\hline \multicolumn{7}{|c|}{ Model Summary } \\
\hline 1.Type of bank & Model & $\mathrm{R}$ & $\mathrm{R}$ Square & Adjusted R Square & $\begin{array}{c}\text { Std. Error of the } \\
\text { Estimate }\end{array}$ \\
\hline ICICI & 1 & $.501^{\mathrm{b}}$ & .251 & .243 & .877 \\
\hline \multicolumn{6}{|c|}{ a. Predictors: (Constant), assurance, tangibility, Reliability, Responsiveness, empathy } \\
\hline
\end{tabular}

The regression table summarizes the model performance through the following statistics

R: reveals the multiple correlation coefficients. It range lies between 0 to +1 . Since the $\mathrm{R}$ value ICICI banks is 0.501 respectively. It means reliant variable (customer satisfaction towards retail banking services) has positive relationship with independent variables (tangibility, reliability, responsiveness, empathy, assurance).
R square: reveals the coefficient of determination and ranges between 0 and 1 . Since the R square value of ICICI bank is 0.251 respectively. It means that $30.5 \% \& 25.1$ of the variation explained by in reliant variable (customer satisfaction towards retail banking services) in terms of independent variables (tangibility, reliability, responsiveness, empathy, assurance).

\section{G. $A N O V A^{a}$}

Table No: 4

\begin{tabular}{|c|c|c|c|c|c|c|c|}
\hline Type of bank & \multicolumn{2}{|c|}{ Model } & Sum of Squares & $\mathrm{df}$ & Mean Square & $\mathrm{F}$ & Sig. \\
\hline \multirow{3}{*}{ ICICI } & \multirow{3}{*}{1} & Regression & 127.810 & 5 & 25.562 & 33.239 & $.000^{\mathrm{c}}$ \\
\hline & & Residual & 381.443 & 496 & .769 & & \\
\hline & & Total & 509.253 & 501 & & & \\
\hline
\end{tabular}

From the above ANOVA table $\mathrm{F}$ values are significant (significant values are less than 0.05 ) it means reliant variable (customer satisfaction towards retail banking services) is more reliable.

\section{H. Standardised and Unstandardized coefficients}

Table No: 5

\begin{tabular}{|c|c|c|c|c|c|c|c|}
\hline \multicolumn{8}{|l|}{ Coefficients $^{\mathbf{a}}$} \\
\hline \multirow[t]{2}{*}{ Type of bank } & \multirow{2}{*}{\multicolumn{2}{|c|}{ Model }} & \multicolumn{2}{|c|}{ Unstandardized Coefficients } & \multirow{2}{*}{\begin{tabular}{|l} 
Standardized \\
Coefficients \\
Beta \\
\end{tabular}} & \multirow[t]{2}{*}{$\mathrm{t}$} & \multirow[t]{2}{*}{ Sig. } \\
\hline & & & B & Std. Error & & & \\
\hline \multirow{6}{*}{ ICICI } & \multirow{6}{*}{$\mid 1$} & (Constant) & 1.382 & .182 & & 7.579 & .000 \\
\hline & & Tangibility & .112 & .035 & .131 & 3.233 & .001 \\
\hline & & Reliability & .116 & .055 & .117 & 2.113 & .035 \\
\hline & & Responsiveness & .349 & .056 & .314 & 6.203 & .000 \\
\hline & & Empathy & .043 & .056 & .045 & .765 & .445 \\
\hline & & Assurance & .035 & .044 & .043 & .791 & .429 \\
\hline
\end{tabular}

The above model coefficients are used to construct the regression lines. This model helped to recognise the most influencing factors according to client priorities.

In ICICI the low significant values of $<0.05$ of the variables tangibility, reliability and responsiveness are showing very strong significant impact on dependent variable (client satisfaction towards retail banking services). The high significant value of $>0.05$ of the variables empathy and assurance are showing very less significant impact on reliant variable (client satisfaction towards retail banking services). 


\section{Identification and Prioritisation of Impact Factors in Quality Service Of ICICI Bank with Special Reference to Urban Cities of Telangana State}

The required regression lines of ICICI bank is

Client satisfaction towards retail banking services $=1.382+$ 0.112 (tangibility) +0.116 (reliability) +0.349 (responsiveness) +0.043 (empathy) +0.035 (assurance)

\section{RESULTS AND DISCUSSION}

\section{Hypothesis Test Analysis}

From data analysis tables of the correlation and regression line developed we can purely reject the null hypothesis framed and can conclude that factors of quality merely influence the client satisfaction of the concerned districts of the Telanagana.

From the correlation table it is perfect that client satisfaction towards retail banking services of ICICI is positively correlated with Tangibility, Reliability, Responsiveness, empathy, assurance and responsiveness is little bit highly correlated to client contentment.

The research aims to make a real role of examining the impact of the retail services with SERVQUAL measures over the customer contentment done with the services of the ICICI bank. A number of magnitudes of the retail facilities of the bank were studied which requires ever ending developments. The study analysed that responsiveness of the banking, reliability and tangibility were the three magnitudes which were having high impact on the satisfaction level of a customer whereas empathy stood next and then assurance being the least of the factors influencing the content levels of the clients. Banks have to focus on the level of bearing on the customers which are at least to improve and reach a standard so that they can catch the eye of a consumer and build the client relationship with more determination in long run overcoming with development of trust in weaker areas. Empathy, assurance, tangibility and reliability stand in a consecutive order of the preference to be focused by the management to strive in the fiercely modest market client relationship has become an obligation and inevitable where the bank has to ponder on. The bank has to be more customer centric by making consumer friendly and painless banking system development.

\section{CONCLUSION AND FUTURE SCOPE}

The researcher has identified the significance of the service quality factors are greatly influencing over the client contentment and the management of the bank has to focus on the least value factors found in the correlation and regression to improve the effort less banking and satisfaction of the clients. In fact this policy retents the client base and thus leads with growing revenues to bank. Customer centric attitude will definitely bring up the retention and loyalty of the client with the bank. Management has to try with the new selling style with automation of the frontline office developments which lead with developed sales and out leap opponents in the market. The improved humanistic approach empathetically efficient behaviour of staff, quicker delivery of transaction, developing high trust with the client with accurate and right transactions leads to catch the heart of the old customers and develops the scope of adding new ones to banks.

The research taken up is limited with study done in the client's satisfaction of retail banking services with certain few important dimensions and it has been done in private bank with restricted areas of sampling considered. In future there is scope of the study to be extended to various numerous dimensions and with many other bank branches in public and even private sector banking too.

\section{REFERENCES:}

[1] Yavas and Babakus, "measuring service quality of banks: Scale development and validation", Journal of Retailing and Consumer Services 12(5): pp. 373-383. September 2005

[2] Winstanley,M., "What Drives Customer Satisfaction in Commercial Banking", Commercial Lending Review, 1996, 12(3): pp. 36-42.

[3] Churchill Jr. and G.A. Suprenant C "An Investigation into the Determinants of Customer Satisfaction. Journal of Marketing Research (JMR), 1982, 19,pp. 491-504.

[4] Parsuraman et.al. , Parasuraman, A., Zeithaml, V.A. and Berry, L.L. , "SERVQUAL: A Multiple Item Scale for Measuring Consumer Perceptions of Service Quality", Journal of Retailing, 1988, Vol. 64, No. 1, pp.14-40

[5] Gronroos, C., "Quo vadis, marketing? Towards a relationship marketing paradigm", Journal of Marketing Management, 1994, Vol. 10, pp. 347-60

[6] Christian Grönroos "A Service Quality Model and its Marketing Implications", European Journal of Marketing, 1984, Vol. 18 No. 4, pp. 36-44

[7] Cadott et al., Inc. " Distinguishing Service Quality and Customer Satisfaction: The Voice of the Consumer", Journal of Consumer Psychology, Lawrence Erlbaum Associates, 1987, 4(3), 277-303 Copyright 01995

[8] Fornell, C., "A National Customer Satisfaction Barometer: The Swedish Experience", Journal of Marketing,1992, 56, pp. 6-21., https://doi.org/10.2307/1252129.

[9] Zeithmal et al., "service quality, customer satisfaction in technology - based universities", African Journal of Business Management, 4 August, 2011 "Vol. 5(15), pp. 6541-6553

[10] Oliver, R. L., "Satisfaction: A Behavioural Perspective on the Consumer", New York, McGraw Hill,1997.

[11] Storbacka, K., Strandvik, T. \& Grönroos, C., "Managing Customer Relationships for Profit: The Dynamics of Relationship Quality", International Journal of Service Industry Management, Sept 1994, pp. 21- 38. 